\title{
Die relevansie van die gereformeerde teologie vir vandag
}

The problem in South Africa has not been Calvinism but rather, with some notable exceptions, the absence of a truly Reformed theology, one in which prophetic critique and evangelical transformation combine to serve the liberation of those crying out for life. (De Gruchy, 1991:34.)

\section{J.H. van Wyk \\ Departement Dogmatologiese Vakke \\ Potchefstroomse Universiteit vir $\mathrm{CHO}$ \\ POTCHEFSTROOM}

\begin{abstract}
The relevance of Reformed theology today

In this essay the author has tried to summarise the key features and to rethink the relevance of Reformed theology. In this connection the idea that Reformed theology' can be reduced to one basic motive is questioned: it is argued that six characteristics of Reformed theology should rather be distinguished and applied interrelatedly. The issue as to why Reformed theology in South Africa to a large extent failed to reject the ideology of apartheid is also touched upon.
\end{abstract}

\section{Inleiding}

Om gelowig en wetenskaplik na te dink oor die relevansie van die gereformeerde teologie vir vandag is 'n opgawe wat nie maklik uitgevoer kan word nie, in elk geval nie in een artikel nie. Talle vrae roep om beantwoord te word. Wat is teologie? Wat is gereformeerde of Gereformeerde teologie? Wat bedoel ons met vandag?

Oor die vraag - eerstens - wat ons onder teologie verstaan, hoef ons nie lank uit te wei nie, aangesien dit ons te ver van ons eintlike tema sou weglei. Vir ons doel is dit voldoende om te stel dat teologie te maak het 
met die gelowige en wetenskaplike nadenke oor die Woord van God (die Skrif) en daarom oor die God van die Woord (Kuyper, 1909:199; Wentsel, 1981:18-20, 30). Die gedagte om Gód te kén, is 'n volledig Bybelse gedagte (Kol. 1:10; 2 Pet. 1:2). God en sy Woord moet uiteraard duidelik van mekaar onderskei word, maar mag nie van mekaar geskei word nie. Die Skrif is die selfmededeling van God en dit openbaar God se heil vir die mens en sy heling van die wêreld. Dit is onmoontlik om met die Skrif om te gaan sonder om daarin die stem van die lewende God te hoor en met Hom gekonfronteer te word. Teologie probeer hierdie spreke van God in sy betekenis vir mens, kerk en wêreld nadink, vertolk en verduidelik - en realiseer.

Teologie is daarom geloofswetenskap (Bavinck, 1928:584). Sonder geloof is teologie nie moontlik nie (Roscam Abbing, s.j.:175; Ridderbos, 1968: 191, 194; Van Genderen, 1975:15). Vandaar ook dat die gebed so 'n onmisbare plek in die teologie en in die lewe van 'n teoloog sal inneem (Rossouw, 1990:71; vgl. Barth, 1988:159-170; Berkhof, 1990:478-485). Teologie is theologia orans. Christelike spiritualiteit speel ook hier 'n belangrike rol, ook gereformeerde spiritualiteit (vgl. o.a. Smit, 1988:182193; Jonker, 1989a:288-299; Nicol, 1989:48-63; Velema, 1990; Rice, 1991; Ramey \& Johnson, 1991). Goeie teologie is slegs te vind waar die teoloog daarin slaag om wetenskaplike bekwaamheid sinvol met spirituele begaafdheid te verbind (vgl. Du Toit, 1988:11). Wie geloof as vertrekpunt in die teologie neem, hoef daardeur geensins aan wetenskaplikheid in te boet nie. Credo ut intelligam.

'n Tweede vraag is wat ons onder die term gereformeerd moet verstaan? Moet ons dit met 'n kleinletter $\mathbf{g}$ of 'n hoofletter $\mathbf{G}$ spel? Bedoel ons daarmee dieselfde as 'evangelies' en 'reformatories' (Runia, 1984)? Sluit dit teoloë soos F. Schleiermacher, K. Barth, E. Brunner, O. Weber en J. Moltmann in of uit (Klooster, 1979:35)? Of bedoel ons eerder die teologiese denklyn wat vanaf Calvyn oor Bavinck en Berkouwer loop?

Daar was tye - in die begin van hierdie eeu - toe verskeie gereformeerde teoloë eksplisiet gereformeerde teologie beoefen het. Hier kan gedink word aan H. Bavinck se Gereformeerde Dogmatiek $1-4$, T. Hoekstra se Gereformeerde Homiletiek en W. Geesink se Gereformeerde Ethiek 1 - 2. Sedert die middel van hierdie eeu het daar (in Nederland) 'n meer ekumeniese benadering in die teologie begin posvat en lewer G.C. Berkouwer sy agtien dele Dogmatische Studiën en G. Brillenburg Wurth drie dele Het Christelijk Leven. Teen die einde van die eeu skryf B. Spoelstra egter 
weer 'n handboek oor Gereformeerde Kerkreg en Kerkregering (1989) en J. van Genderen en W.H. Velema 'n Beknopte Gereformeerde Dogmatiek (1992).

Dit is 'n boeiende vraag waarin die eie-aard van die gereformeerde teologie gesoek moet word. Wat is die tipiese kenmerke daarvan en hoe sou dit gekarakteriseer moet word sodat dit byvoorbeeld duidelik van die RoomsKatolieke, Oosters-Ortodokse, Lutherse, Anglikaanse en Pinksterteologieë onderskei kan word? Moet dit dalk in een of ander sentrale gedagte of kerndogma gesoek word (vgl. Jonker, 1974:255)? Dit word lank nie meer aanvaar nie - soos sommige gemeen het en meen (Bavinck, 1928:7, 151; De Gruchy, 1991:111) - dat Luther se teologie antroposentries is, omdat dit die heil van die mens vooropstel, en die teologie van Calvyn teosentries is, omdat dit vir hom om die eer van God gaan (Jonker, 1974:249; König, 1978:172, 197; Runia, 1984:41; Van Wyk, 1984:4, 17; Berkhof, 1990: 417). Só teenstellend moet die heil van die mens en die eer van God nie gedink word nie, in elk geval nie binne 'n verbondsteologie nie. Die opmerking is ook al gemaak dat die Middeleeuse teologie 'n teologie van die liefde was, dié van die Reformasie 'n teologie van die geloof en dat ons tans 'n teologie van hoop (en vryheid) beoefen (Moltmann, 1988:33-34).

Daar is al pogings aangewend om die teologiese ontwikkelings in bepaalde gereformeerde kerkgemeenskappe in Nederland en Suid-Afrika hierdie eeu kursories weer te gee (Veenhof, 1992:14-95; Van Wyk, 1980:27-50), maar tot 'n afsluitende geheel is nie gevorder nie. Verskeie teoloë het getrag om die gereformeerde teologie te beskryf en vir die mees resente pogings kan verwys word na Van Ruler (1971:78-100), Jonker (1974:253-260), König (1978:169-173; 189-202) Brown (1979:437-469), Klooster (1979:32-54), Hesselink (1983:93-112), Van Genderen (1992:21-26). Al hierdie pogings lewer belangrike boustene vir die uitbouing van 'n gereformeerde teologie (vgl. Van Wyk, 1986; Van der Walt, 1991). Natuurlik is daar ook uitgebreider werke as bogenoemde, soos byvoorbeeld dié van Osterhaven (1971), Leith (1977), Hesselink (1983) en McKim (1992). Uiteraard is Calvyn se Institusie die hoofnaslaanwerk, terwyl (resente) studies oor Calvyn se teologie soos dié van Wendel (1978), Niesel (1980), Bouwsma (1988) en McGrath (1991) van groot waarde is.

Self is ek van mening dat die denklyn Calvyn-Bavinck-Berkouwer - 'n denklyn wat reeds by Augustinus begin - die meeste aanbeveling verdien (vgl. Noordmans, 1979:184; Spykman, 1992:22). Daarmee is natuurlik nie gesê dat met alles van hierdie teoloë saamgestem word nie, want ook 
hiér is 'n kritiese solidariteit gepas. Geen teologiese insig mag immers sito-sito met 'n Skrifwaarheid geïdentifiseer word nie - en met hierdie stelling het ek natuurlik my kaarte op tafel geplaas. Ek gaan hier handel oor gereformeerde teologie (met 'n kleinletter $\mathbf{g}$ ), veral soos daardie teologie binne die referensiekader van die Drie Formuliere van Eenheid funksioneer. Daarmee is dan nié gesê of geïmpliseer dat teologieë wat buite hierdie raamwerk funksioneer, noodwendig ongereformeerd sou wees nie. Ek stel my ten doel om die belangrikste kenmerke van die gereformeerde teologie uit te spel en krities te ontleed en so die relevansie daarvan bloot te lê.

'n Derde voorafopmerking moet gemaak word. Wat bedoel ons as gevra word na die relevansie van die gereformeerde teologie vir vandag? Bremmer (1991:34-36, 112) het daarop gewys dat die twintigste-eeuse teoloog te doen kry met 'n paar magtige denkverskuiwings wat hy nie kan ignoreer nie. Daar is, om te begin, die veranderde Godsheeld; die transendensie van God het in gedrang gekom en daar word selfs van 'n Godsverduistering gepraat (Buber). Daar is voorts die veranderde wêreldbeeld, naamlik 'n geslote wêreldbeeld. Dan is daar nog die veranderde mensbeeld, met sy kenmerke van mondigheid en outonomie. Hierby kan gevoeg word die veranderde wetenskapsbeeld met sy rasionalisme en sciëntisme. Die volgende vrae is ter sake: Hoe funksioneer die gereformeerde teologie binne hierdie veranderde denkpatrone? In watter mate moet daar van paradigmaverskuiwings in die teologie gepraat word? (Küng \& Tracy, 1989:3-33).

Waarskynlik het die gereformeerde teologie in Suid-Afrika nog nie die volle aanslag van bogenoemde denkskemas ervaar nie, maar wat ons wél ervaar het, is die geweldige suigkrag wat ' $n$ bepaalde (politieke) ideologie op die teologie uitgeoefen het. So word die gereformeerde teologie verwyt dat dit sy profetiese gehalte verloor het (De Gruchy, 1991:34), dat dit meer belang gestel het in konfessionele en kerklike probleme as in die sosiale betekenis van die gereformeerde tradisie (De Gruchy, 1991:33) én dat dit skuldig is aan 'n dubbele sonde: dit het misluk om apartheid te verhoed en dit het daarin geslaag om dit te regverdig (De Gruchy, 1991:31). Hierdie kritiek moet besonder ernstig geneem word, selfs al word die simplisme verwerp (wat meen) dat die oorsprong van apartheid aan die Calvinisme toegeskryf moet word (De Gruchy, 1991:12). 


\section{Gereformeerde teologie is teosentriese teologie}

Een van die hoofkenmerke van die gereformeerde teologie is dat dit begin waar die Skrif begin: met God. Die Godsleer is van fundamentele betekenis. Klassieke voorbeelde hiervan is - ofskoon dit nie in die eerste plek teologiese dokumente is nie - artikel 1 van die Nederlandse Geloofsbelydenis wat handel oor "die enige God" asook Calvyn se Geneefse Kategismus wat begin met die vraag: "Wat is die belangrikste doel van die mens se lewe?", en die antwoord: "Om God deur wie die mens geskape is te leer ken". Die laaste grond waarin die geloof veranker is, is nie die Bybel nie maar God (Kuitert, 1992:292). Die gereformeerde teologie ken geen bibliolatrie nie, slegs deolatrie.

Alle regte denke oor God ontspring uit die ontmoeting met God en is gerig op die ontmoeting met God (Berkhof, 1960:14:15, 1990:29).

Vandaar dat die slagspreuk soli Deo gloria so 'n besondere aksent ontvang. Vandaar ook dat sommige teoloë die soewereiniteit van God as dié Calvinistiese beginsel beskou, sowel vir die dogmatiek (Lecerf, 1981:375385; vgl. George, 1988:310-314; Jonker, 1994:36) as vir die etiek (Van Egmond, 1992:296). Die hartaar van die gereformeerde tradisie bestaan inderdaad in 'n lewe coram Deo (Osterhaven, 1971:7-8, 88-109; Leith, 1977:67). Die besondere verhouding tussen God en mens is in die gereformeerde teologie deurgedink selfs tot "op die punt van die belydenis van die dubbele predestinasie" (Jonker, 1974:256) - 'n konsekwensie wat Jonker (1989b:141-148) egter nie volledig kon volhou nie (vgl. Jonker, 1994:37).

Die gereformeerde teologie is sonder hierdie teosentriese eienskap onverstaanbaar (Van Genderen, 1975:22; vgl. König, 1978:191-193; Hesselink, 1983:94-97).

Wie egter die woord teosentries gebruik, sê noodwendig daarmee saam trinitaries: gereformeerde teologie is trinitariese teologie (vgl. Van Ruler, 1978:1-28; Jonker, 1994:5, 19, 53), dit wil sê 'n teologie waarin die Patrologiese, Christologiese en Pneumatologiese dimensies verdiskonteer word. Gereformeerde teologie handel oor God die Vader en ons skepping, oor God die Seun en ons verlossing en oor God die Heilige Gees en ons heiligmaking (vgl. HK 8:24), die een nie ten koste van die ander nie.

Calvyn het in boek III van sy Institusie die Pneumatologie baie sterk ontwikkel terwyl by Barth die Christologiese toespitsing opvallend is. Daar 
moet egter nougeset gewaak word teen 'n onderbeklemtoning van die werk van God die Vader, aangesien die sola gratia juis vanuit die Váderliefde deursigtig word (Ef. 2:8). Die gereformeerde teologie aanvaar dat God homself finaal in Jesus Christus geopenbaar het en dat ons God nie buite Christus om waarlik kan ken nie (Joh. 14:6), maar gaan nie daarmee in 'n Jesulatrie op nie. Gereformeerde teologie bly trinitariese teologie. Sowel die Patrologie (König, 1978:172) as die Christologie (König, 1978:189191), asook die Pneumatologie (Hesselink, 1983:73-84), moet, in onlosmaaklike verbondenheid, aandag ontvang. Hierdie trinitariese benadering is van beslissende betekenis vir élke faset van die Christelike leer. So is dit byvoorbeeld onaanvaarbaar om die voorsienigheidsleer en predestinasieleer buite Christus om te ontwikkel. Of Calvyn (en die gereformeerde teologie) die uitverkiesingsleer tot cor ecclesiae ontwikkel het, soos Kuyper (1893: 161) geoordeel het, moet betwyfel word (Wendel, 1978:264-265; George, 1988:232-234; Jonker, 1989b:121-131; McGrath, 1991:166-169, 208218). Wat die sondeleer en verlossingsleer betref, dink die gereformeerde teologie Augustiniaans en anti-Pelagiaans. Omdat die sonde so radikaal is (corruptio totalis) (vgl. Bouwsma, 1988:139; De Gruchy, 1991:151), daarom moet die verlossing so radikaal wees.

In 'n sekere sin is dit die Christologie wat die teologie ontsluit (vgl. Spykman, 1992:84). Volgens Bavinck (1929:254) is die Christologie nie die uitgangspunt nie maar wel die middelpunt van die ganse dogmatiek; "in haar als het hart der dogmatiek klopt heel het religieus-ethische leven der Christenheid". Dit is immers so dat die Ou Testament van Christus getuig (Luk. 24:27), dat dit kennis kan bybring wat tot verlossing lei deur die geloof in Christus Jesus (2 Tim. 3:15) (solo Christo) en dat God se openbaring in Christus 'n hoogtepunt bereik (Heb. 1:1) (Inst. 4.8.7). Johannes skryf sy hele evangelie om mense tot die geloof te bring dat Jesus die Christus is, die Seun van God, en dat hulle die lewe kan hê deur te glo in sy Naam (Joh. 20:31). Die belydenis van die kruisiging en opstanding van Jesus Christus is van deurslaggewende betekenis en tipeer die gereformeerde teologie as 'n theologia crucis (Moltmann, 1988:48), terwyl 'n theologia gloriae slegs vanuit die opstanding van Christus en in eskatologiese perspektief ter sprake kom. Die gereformeerde teologie vra ook besondere aandag daarvoor dat Christus die enigste en volkome Verlosser is (solo Christo) asook vir sy universele heerskappy. Hy heers nie net in die kerk nie (Inst. 4.9.1), maar ook in die samelewing, ja oor die ganse skepping. 


\section{Gereformeerde teologie is Skriftuurlike teologie}

Daar heers wydverspreide konsensus dat een van die hartare van die gereformeerde teologie in sy Skrifgebondenheid gesoek moet word. Goeie teologie is Skriftuurlike teologie (Jonker, 1974:245; Hesselink, 1983:97102; George, 1988:314-317; Jonker, 1994:28-29; vgl. König, 1978:170). Die Skrif is die bron en norm van die teologie (Klooster, 1979:43; Bremmer, 1991:37-60). Natuurlik is God ook op 'n bepaalde wyse deur middel van die skepping, onderhouding en regering van die wêreld kenbaar, maar Hy het Hom deur sy Goddelike Woord "nog duideliker en meer volkome" bekend gestel (NGB art 2).

Ons mag geen geskrifte van mense, hoe heilig die mense ook al was, met die Goddelike Skrif gelykstel nie; ook mag ons nie die gewoonte of die groot getalle of oudheid of opvolging van tye of van persone of kerkvergaderings, verordeninge of besluite met dié waarheid van God gelykstel nie, want die waarheid is bo alles. (NGB art 7.)

Die waarheid van die Skrif bo alles! Aan die Skrifopenbaring kom 'n meerwaarde toe teenoor die natuuropenbaring (vgl. Jonker, 1994:57-58).

Waarom? Omdat dit in die teologie ten diepste gaan oor waarhede waaroor die mens nie beskik nie maar wat aan hom geskénk moet word (Roscam Abbing s.j.: 181); omdat dit oor waarhede gaan wat die mens nie self uitgedink het nie - of kon uitdink nie - maar wat aan hom geopenbaar is (vgl. Matt. 16:17; 1 Kor. 12:3). Wie die openbaringskarakter van die Skrif aantas, en dit byvoorbeeld met 'n ervaringsteologie vervang, tas die hartaar van die gereformeerde Skrifbeskouing en daarmee van die gereformeerde teologie aan (vgl. Klooster, 1979:46, met verwysing na Barth; Berkouwer, 1974:67; Spykman, 1992:74).

Daarom is Kuitert se siening dat "alles wat wij over boven zeggen, komt van beneden" (Kuitert, 1992:23 vgl. 1974:28), dat Christelike waarhede van mense afkomstig is (Kuitert, 1992:30) en dat die Bybel niks meer of minder bevat as wat Israel oor God en die evangeliste en apostels oor Jesus gedink het nie (Kuitert, 1992:293), 'n deursny van die hoofsenuwee van die gereformeerde teologie. Die noodwendige konsekwensie hiervan is 'n subjektivistiese, intellektualistiese en immanentistiese teologie.

Die sola Scriptura kan in 'n sekere sin beskou word as dié kenmerk van die Reformasie (Klooster, 1979:39, 51; Graafland, 1973:34-50, 94; vgl. Spykman, 1992:59, 70, 72, 87) en van die gereformeerde teologie. Geen wonder nie dat Calvyn die bediening van die Woord as die hoofsenuwee en 
siel van die kerk beskou het (Inst. 4.2.7). Met sy aksent op die sola Scriptura het die gereformeerde teologie stelling ingeneem teen elke vorm van naturalistiese, kerkistiese, tradisionalistiese, antroposentristiese en rasionalistiese teologie. Nie die natuurorde, nie die kerklike uitsprake, nie die kerklike tradisie, nie die standpunte van kerkvaders (Inst. 4.9.8/9), nie die menslike rede nie, maar slegs die Skrif is vir die gereformeerde teologie van deurslaggewende betekenis. (Opvallend is dat sedert Vaticanum 2 ook in die Rooms-Katolieke teologie 'n groter aksent op die Skrif geplaas word. So verklaar Dei Verbum (1966:36-39) dat die heilige teologie tot blywende grondslag die geskrewe woord van God tesame met (cum) die heilige Oorlewering het en dat die studie van die heilige Skrif as't ware die siel van die heilige teologie moet wees.) Gereformeerde teologie is in 'n sekere sin niks anders as Woordbediening nie en die beoefening van teologie impliseer liturgie.

Hiermee is natuurlik nog nie alles gesê nie. Die sola Scriptura moet met die tota Scriptura aangevul word: die héle Skrif is gesaghebbende Woord van God. Ou en Nuwe Testament, wet en evangelie is Woord van God en staan nie kompeterend teenoor mekaar nie - soos in ' $n$ bepaalde sin in die Lutherse teologie te vind is - maar is komplementerend tot mekaar (vgl. Jonker, 1974:257-260). Ook die Ou Testament is volledig deel van die Godsopenbaring sodat Van Ruler (1971:85) tereg opmerk dat "het Oude Testament speelt nergens in de christenheid zo 'n grote en eigen rol als in de gereformeerde". Inderdaad speel die exodus-motief in die bevrydingsteologieë 'n deurslaggewende rol, maar dan moet daarby gesê word dat hierdie teologieë die Ou Testament (en Bybel) op uiters reduksionistiese en selektiewe wyse hanteer (Klooster, 1979:49, 50).

'n Verdere aspek wat vermelding verdien, is dat die volle Woord vir die volle lewe geld (Jonker, 1974:254). Dit is waar dat die Skrif 'n bepaalde skopus besit - dit leer "alles wat die mens vir sy saligheid moet glo" (NGB art 7) maar dit impliseer geensins dat die Skrif geen lig vir die volle lewe bevat nie - Inteendeel (vgl. Ps. 119:105). Die Skrif het groot waarde om 'n regte lewenswyse te kweek (2 Tim. 3:16). Die gereformeerde teologie gaan daarvan uit dat die Skrif die Woord van God is sowel vir die kerk as die politiek, vir die individu as vir die samelewing, vir die gees as vir die liggaam (George, 1988:321). Daar val geen skadukolle waar die lig van die Goddelike Woord nie skyn nie. Dit dring deur tot in die diepste wese van die mens (Heb. 4:12). 
'n Laaste aspek moet vermeld word, en dit handel oor die regte verstaan van die Skrif. Hiermee is een van die moeilikste moderne vraagstukke die hermeneutiese vraag - in verband met die Skrifleer aan die orde gestel. Die belydenis dat die Skrif die gesagvolle Woord van God is, waarborg immers nie vanself dat die Skrif reg verstaan en verantwoordelik uitgeleef sal word nie. Die erkenning van formele Skrifgesag is onvoldoende indien dit nie opgevolg word met 'n daadwerklike gehoorsaamheid aan die boodskap van die Skrif nie (Berkouwer, 1969:183; 1974:192; Jonker, 1973:86-111). Dooie ortodoksie is niks anders as 'n vorm van Bybelkritiek nie (Veenhof, 1992:42, met verwysing na Bavinck).

Teologie is in 'n baie groot mate 'n hermeneutiese dissipline waarin die vraag hoe die Skrif verstaan word, sentraal staan (Rossouw, 1990:64-65; vgl. Du Toit, 1967:12-13; Du Toit, 1988:12, met verwysing na Ebeling). Al hoe meer dring die besef deur dat bepaalde sosiologiese, psigologiese, ekonomiese en politieke voorveronderstellings medebepalend en soms selfs deurslaggewend is in die Skrifverstaan (vgl. Van Huyssteen, 1986:194; Küng \& Tray, 1989:5, 23; Maimela, 1990:177; Spykman, 1992:96, 120). So word daar gevra dat die Skrif 'n keer gelees moet word deur die bril van die onderdrukte - in plaas van die onderdrukker - ten einde sy ware betekenis te verstaan (De Gruchy, 1991:71-79; vgl. West, 1991). Daar word selfs gepraat van 'n 'hermeneutiek van agterdog' - die mens is immers sondaar. Hierop moet die gereformeerde teologie antwoord dat daar wel sprake kan (en moet) wees van 'n 'hermeneutiek van agterdog' sover dit die konteks aangaan, terwyl van 'n 'hermeneutiek van vertroue' uitgegaan word sover dit die Teks betref. Gereformeerde teologie is onmoontlik indien die Skrifboodskap apriories betwyfel word.

Of die teologie vir 'n bepaalde (Christelike) filosofie as prolegomena moet kies, soos Spykman (1992:7, 13, 39, 97, 101, 107) oordeel, moet myns insiens betwyfel word. Teologie behoort van teologiese (in elk geval geloofs-) voorveronderstellings uit te gaan.

Juis vanweë sy aksent op die Skrif loop die gereformeerde teologie voortdurend gevaar om hom aan fundamentalisme skuldig te maak en om in skolastisisme en ortodoksisme te verval (vgl. Van Huyssteen, 1986:195196). Geïsoleerde en ongeëksegetiseerde Bybeltekste word dan agter 'n teologiese stelling ingeryg om die waarheid daarvan te 'bewys'. Só 'n Skrifhantering maak geen erns met die eie aard van die Skrifgesag en met die teks binne konteks, en kom (onbedoeld) by dieselfde punt as 'n Skrifkritiese benadering uit, naamlik dat die gesag van die Skrif ondermyn en sy 
boodskap verkeerd verstaan word. Dogmatici (vgl. Jonker, 1973:90, met verwysing na Berkouwer) en etici het 'n redelike mate van sensitiwiteit ten opsigte van die Skrifberoep ontwikkel, maar dit moet betwyfel word of hierdie sensitiwiteit na al die ander teologiese dissiplines deurgedring het.

Die gereformeerde teologie maak in sy Skrifverstaan graag van 'n hele aantal hermeneutiese riglyne gebruik - die vermelding waarvan te veel plek sou neem (Van Wyk, 1989:51-54). Eén daarvan is - en dit het reeds Calvyn (Inst. 3.2.33, 4.8.13, 4.9.1) geleer - dat Woord en Gees nie van mekaar losgemaak mag word nie. Die Woord rig sonder die verligting van die Gees niks uit nie (Inst. 3.2.33), maar daarmee is die Gees nie tot 'n slaaf van die Woord verlaag nie (Inst. 4.16.19).

Teen die agtergrond van die Skrifgebondenheid van die gereformeerde teologie, is die vraag gewettig of daarmee ruimte vir eksperimente - wat eie is aan elke wetenskap - uitgesluit is. Gereformeerde teoloë oordeel hieroor negatief (Ridderbos, 1968:192; Van Genderen, 1975:20-21; Du Toit, 1986:399; Spykman, 1992:110). Nie alle waarhede is in die gereformeerde konfessies vasgelê nie (Bavinck, 1928:6) en die gereformeerde teologie het onder andere tot taak om die Skrifwaarhede nougeset na te vors en uit te diep. As 'n gereformeerde teoloog oortuig sou raak dat die gereformeerde belydenis op 'n bepaalde punt met die Skrif in stryd is, dan moet hy kragtens sy ondertekeningsformulier 'n gravamen by 'n kerkvergadering indien. Die teoloog is binne die raamwerk van die Skrif volkome vry, maar dit is altyd 'n verantwoordelike vryheid.

\section{Gereformeerde teologie is kerklike teologie}

Die stelling dat gereformeerde teologie kerklike teologie is, is nie vanselfsprekend nie. Kuyper (1909:548-554) was byvoorbeeld van mening dat die teologie vry moet wees van kerklike oorheersing en ook Van Ruler (1971:78) oordeel dat teologie nie 'n funksie van die kerk is nie (vgl. Deist, 1994:53-67). Daarteenoor stel Barth (1955:1) onomwonde dat teologie wel 'n funksie van die kerk is (vgl. Wentsel, 1981:22-24,31). Die gereformeerde teologie sluit graag aan by die modelle wat in die Skrif self na vore tree: in die Ou Testament die profeet en profeteskole, in die Nuwe Testament Christus en sy dissipels, Paulus en sy helpers: almal voorbeelde van T/teologie-beoefening uit en vir die kerk - al sal nog méér gesê moet word (vgl. pt. 6). Miskien moet ons sê dat die gereformeerde teologie kerklik is maar nie kerksentries nie (Bosch, 199lb:16; vgl. Ridderbos, 1968:194196). Die onmiddellike konteks waarbinne die teoloog teologie beoefen, is 
die kerk van Christus. Kerk en teologie staan in 'n wederkerige verhouding tot mekaar en mag nie van mekaar geïsoleer word nie (vgl. Kühn, 1985:98-115). 'n Kerk sonder teologie is net so 'n onding as 'n teologie sonder kerk. Bavinck (1928:585) het dit uitstekend geformuleer toe hy gesê het dat die geloof (kerk) die teologie van sekularisasie bewaar terwyl die teologie die geloof (kerk) van separatisme bewaar. Die gevare van klerikalisering en sektarisme moet vermy word (Bosch, 1991b:7).

'n Kerk sonder teologie is soos 'n motor sonder vuur. Natuurlik leef die kerk nie van teologie nie maar van die lewende Woord (vgl. Berkouwer, 1969:187). Die teologie moet egter die Woord op sodanige wyse vir die gelowiges en die kerk ontsluit dat die prediking, pastoraat, kategese en gemeentebou daarby baat. Daarom is goeie gereformeerde teologie altyd pastorale teologie (en nie ivoortoring-teologie nie) soos byvoorbeeld in Calvyn se Institusie te sien is. Tereg is daarvoor gepleit dat teoloë nie net predikante moet oplei nie maar betrokke moet wees by die toerusting van alle gelowiges (Cochrane, 1993a:20-21). Die teologie moet ook kerkvergaderings dien sodat weldeurdagte besluite geneem kan word (Du Toit, 1986:397). Daar word dikwels gesê dat kerkvergaderings regeerliggame en nie studieliggame is nie - 'n argument wat soms gebruik word om lastige sake gou af te handel. Daar is egter weinig sake wat meer afbrekend is vir kerklike verhoudinge as ondeurdagte, onbesonne, ongemotiveerde en teologies-twyfelagtige besluite. Swak besluite tref gereformeerde kerke nog swaarder as ander kerke omdat gereformeerde kerke immers pretendeer dat juis húlle erns maak met die Skriftuurlike fundering van besluite.

Die teologie moet die kerk ook help om sy profetiese roeping in die samelewing na te kom (Jonker, 1974:254, 257; König, 1978:198-201; Van Huyssteen 1986:172) - 'n aspek wat in die teologie aan Calvyn nie tot sy reg gekom het nie (teenoor De Gruchy, 1991:251). Die GKSA het op voetspoor van Kuyper se dualistiese kerkbeskouing (en op grond van art. $30 \mathrm{KO}$ ) die profetiese roeping gereduseer tot die optrede van individuele gelowiges, wat wel baie belangrik is (vgl. De Gruchy, 1991:263), asook die Sondagse prediking, maar ten koste van die gesamentlike roeping van kerkvergaderings soos bepaal in artikel 28 van die Kerkorde. Die vraag is nie of die individuele Christen (Kuyper) of wel die kerk (in kerkvergadering) (Barth) 'n profetiese roeping besit nie (vgl. Strauss, 1993:19), maar hoe albe $i$ hierdie roeping behoort uit te leef. 
As kerklike teologie besit gereformeerde teologie ook 'n missionêre gerigtheid, 'n aspek wat sekerlik nie genoeg beligting in die teologie van die Reformasie, die gereformeerde belydenisskrifte en die Dordtse Kerkorde ontvang het nie. Teologie as missiologie moet die evangelie sodanig artikuleer en vertolk dat dit relevant en verstaanbaar grondvat in die wisselende lewensituasies van die voor-moderne, moderne en post-moderne mens.

Teologie kan nie vrugbaar sonder die kerk bestaan nie, het ons opgemerk. 'n Teologie wat die kerk buite rekening laat, is heilloos. Soos wat slegte teologie maklik tot 'n kerkskeuring lei (Roscam Abbing, s.j.:24), so is liberale teologie dikwels kerkverwoestend (Van Genderen, 1975:14). So is konkreet ervaar dat die teologie van Bultmann geen troos bied nie (Du Toit, 1986:395) en dit is bekend dat die liberale teologie van D.F. Strausz en Bruno Bauer geen geringe invloed op die jeugdige Karl Marx uitgeoefen het nie (Raddatz, 1976:33-35).

Dit is wenslik dat teoloë eerder uit die predikantekorps verkies word as daarbuite (Du Toit, 1986:395) en dit is ook wenslik dat 'n teoloog voortdurend kerklik betrokke sal wees (Berkhof, 1982:52; Du Toit, 1986: 396) en dat hy ook gereeld sal preek (Berkhof, 1982:18). Juis daarom is daar soveel meer voordele verbonde aan 'n teologie wat aan 'n seminarium beoefen word as aan 'n suiwer universitêre teologie. Atene en Jerusalem, akademie en kerk, het ongetwyfeld veel meer met mekaar te maak as wat Tertullianus gemeen het (vgl. Berkhof, 1982:43), maar dan moet die verhouding tussen die twee suiwer bedink word. As Paulus hom in $1 \mathrm{Ko-}$ rintiërs 1:20 distansieer van "die wysheid van die wêreld", dan gaan dit spesifiek oor die toenmalige gnosis (Roscam Abbing, s.j.:185) en nie oor wetenskapsbeoefening in die algemeen nie. Dit is waarskynlik ' $n$ ideale situasie vir die beoefening van die teologiese wetenskap indien seminarium en akademie kontraktueel verbind is, elk met sy eie bevoegdheid maar ook met gesamentlike verantwoordelikheid (vgl. Wentsel, 1981:24).

Die teoloog wil in sy teologiebeoefening ook graag deur die kerk vertrou word en dit is vir hom 'n uiters pynlike ervaring as hy moet ontdek dat hy deur die kerk gewantrou of met agterdog bejeën word (Pannenberg, vgl. Bauman, 1990:49).

Teologie en kerk hoort saam. 


\section{Gereformeerde teologie is konfessionele teologie}

Twee aspekte moet hier nader toegelig word, te wete die konfessionele aard van teologie en die teologiese aard van die konfessie.

Die gereformeerde teologie het 'n onmiskenbaar konfessionele aard (vgl. Hesselink, 1983:106-108; Ridderbos, 1968:196). Gereformeerde teologie teologiseer binne die raamwerk van die gereformeerde konfessie en ag homself daaraan gebonde, maar sonder dat dit ooit 'n slaafse gebondenheid is. Die hoogste gesag - norma normans - is slegs die Skrif; die konfessie bly steeds norma normata (Greijdanus, 1946:142; Van Genderen, 1975:13). Van Genderen (1975:4) formuleer selfs dat die konfessie nie die bron nie maar die norm (genormeerde norm!) van die teologie is. Die konfessie staan voortdurend oop vir kritiek en korreksie vanuit die Skrif (vgl. Kuyper, 1909:551-552). Ons het reeds gewys op die moontlikheid van gravamen waar ' $n$ teoloog tot die oortuiging kom dat die belydenis met die Skrif in stryd is.

Op hierdie wyse kan nougeset gewaak word teen die twee gevare wat in hierdie verband 'n permanente bedreiging is: dié van konfessionalisme (waar die konfessie oorskat word) en dié van biblisisme (waar die konfessie onderwaardeer word) (vgl. Van Ruler, 1971:86-88). Konfessionalisme kan immers so maklik die liefde verdring (Veenhof, 1992:46). Die uitspraak 'Skrif en belydenis' moet dus omsigtig gehanteer word en nié in die sin asof hulle gelykwaardig is en dieselfde gesag besit nie. Al word hulle in één asem genoem, staan hulle nog nie op één lyn nie (Van Genderen, 1975:15).

Andersyds besit die konfessie 'n teologiese aard (vgl. Jonker, 1994:1112). Die konfessie moet teologies verantwoord wees en is van minderwaardige gehalte indien die teologiese fundering daarvan twyfelagtig is. Die gereformeerde belydenisskrifte van die sestiende eeu is onverstaanbaar sonder die teologie van Calvyn. Natuurlik is daar 'n onderskeid tussen belydenis en teologie, maar die teologie onderlê die konfessie, belig en bevrug, verklaar en verduidelik dit (vgl. Van Huyssteen, 1986:199-202).

Teologie stimuleer selfs tot nuwe belydenisvorming en moet in elk geval altyd gereed wees om boustene daarvoor te lewer. Dit is feitlik ondenkbaar dat al die eksegetiese arbeid en Skrifondersoek wat sedert die sestiende eeu onderneem is, nie tot nuwe belydenisvorming aanleiding sal gee of daartoe sal uitdaag nie. So was reeds Bavinck van oordeel dat die bestaande gereformeerde konfessies uitgebrei behoort te word ten opsigte van 
die Skrifleer, kerkleer en staatsleer (Bremmer, 1961:384; vgl. Kuyper, 1909:552), 'n tema wat in 1974 in Suid-Afrika geresoneer het (Van Wyk, 1974:22-33). 'n Confessio Africana kan 'n belangrike funksie vervul.

Trouens, dit val op dat die Suid-Afrikaanse kerklike en teologiese terreine teen die einde van die twintigste eeu feitlik oorspoel is met verklarings, boodskappe, getuienisse, dokumente en selfs 'n belydenis (vir 'n oorsig vgl. Van Wyk, 1991:334-337). Baie bekend is die Kairos dokument (1985/6), The Road to Damaskus (1989), Kerk en samelewing (1986/ 1990) en die Belvdenis van Belhar (1986). Waar die eerste twee dokumente kenmerke van die bevrydingsteologie verraai, met 'n tikkie Roomse teologie daarby (vir 'n evaluering, vgl. o.a. Smit, 1991:303-369; Jonker, 1993:443-461; Oosthuizen, 1993:167-187; Jonker, 1994:163-181), staan die Belydenis van Belhar meer in die gereformeerde tradisie. Al hierdie dokumente verset hulle in ' $n$ mindere of meerdere mate teen die ideologie van apartheid. Die Kairos dokument verwerp 'n staatsteologie (Afrikaanse kerke), kritiseer 'n kerkteologie (Engelse kerke) en kies self vir 'n profetiese teologie. In die Belydenis van Belhar word die versoeningsboodskap sterk beklemtoon.

Wat belangrik is, is om te besef dat al hierdie dokumente ' $n$ bepaalde teologiese onderbou besit, uit 'n bepaalde teologie voortkom en selfs 'n bepaalde teologiese struktuur vertoon. Om te sê dat die gereformeerde teologie nie 'n bydrae gelewer het om die ideologie van apartheid te weerspreek nie, is ten minste wat die Belydenis van Belhar betref, nie korrek nie. Trouens, dit is veelseggend dat dit juis binne die gereformeerde tradisie was dat dit tot dogmavorming in Suid-Afrika gekom het.

\section{Gereformeerde teologie is ekumeniese teologie}

Om te dink dat die gereformeerde teologie seksioneel of selfs sektaries sou wees, sou ' $n$ mistasting wees. Dit was nooit die bedoeling van Calvyn om 'n onkatolieke teologie te ontwerp nie en dit was ook nie die bedoeling van sy navolgers nie. So skryf Bavinck in sy voorwoord by sy Dogmatiek I in 1895:

In geen confessie is het christelijke in zijn religieus, ethisch en theologisch karakter zoo tot zijn recht gekomen; nergens is het zoo diep en breed, zoo ruim en vrij, zoo waarlijk katholiek opgevat als in die van de Gereformeerde kerken. (In Van Genderen, 1975:21.) 
Geen wonder nie dat Polman (1969) begin het met die skryf van 'n Gereformeerd Katholieke Dogmatiek, 'n onderneming wat helaas maar net een deel opgelewer het.

"Christen" is my naam en "gereformeerd" my bynaam, het Van Ruler (1973:85) tereg opgemerk. Die gereformeerde teologie het die Reformasie die verste deurgevoer en moet daarom "de meest oecumenische vorm van christendom zijn" (Van Ruler, 1971:80).

Gereformeerde teoloë laat nie na om onophoudelik te beklemtoon dat die gereformeerde teologie ekumeniese (of katolieke) teologie en dus antiskismaties wil wees en daarom in kontinuiteit met die Christelike teologie van alle eeue beofen wil word nie (vgl. Ridderbos, 1968:195; Van Ruler, 1971:78-82; Jonker, 1974:253-255; König, 1978:201-202; Wentsel, 1981: 56; Hesselink, 1983:85-92; Van Huyssteen, 1986:5, 171; Jonker, 1994:16, 18). Gereformeerde teologie wil graag "saam met al die heiliges" (cum omnibus sanctis) probeer begryp hoe wyd en ver en hoog en diep die liefde van Christus strek (Ef. 3:18).

Juis hierdie aspek sou daarvoor sorg dat die gereformeerde teologie steeds 'n nederige teologie sou bly, of altans behoort te wees. En dit nie alleen omdat die gereformeerde teologie steeds bewus was van die voorlopige aard van teologie-beoefening, van die feit dat alle (ook teologiese) kennis "ten dele" is (1 Kor. 13:9), dat eie insigte nooit verabsoluteer mag word, dat teologiese waarheid en Bybelse waarheid nie noodwendig saamval nie, maar ook omdat dit van hoogmoed en oormoed getuig om met teologie besig te wees asof niemand voorheen daarmee besig was en oor die Skrif nagedink het nie. Gereformeerde teologie wil daarom deeglik rekening hou met die teologiebeoefening in die (ook verre) verlede én hede, ook met die nie-gereformeerde teologie.

Gereformeerde teologie wil graag aansluiting vind by die teologie van die kerkvaders en in besonder by dié van Augustinus, omdat hy die skerpste oog gehad het vir die genadekarakter van die evangelie, vir die teosentriese en Skriftuurlike karakter van die teologie. Daarom moet dit as 'n groot leemte aangemerk dat daar in Suid-Afrika te min direkte aandag aan die teologie van die kerkvaders, en in besonder aan dié van Augustinus, tydens die voorbereidingsjare bestee word. Vergelyk in dié verband Noordmans (1981:206) se opmerking dat geen teologiese student die akademie moet verlaat voordat hy nie Augustinus se Confessiones drie maal - en daarby liefs in die oorspronklike taal - deurgelees het nie. Dit is opvallend watter 
groot bydrae teoloë uit Afrika in die teologiegeskiedenis gelewer het: Origines, Cyprianus, Tertullianus, Clemens van Alexandrië, Atanasius en Augustinus (Martey, 1993:72).

Gereformeerde teologie sluit op 'n besondere wyse aan by die teologie van Calvyn - wie se dogmatiese werk wemel van aanhalings uit Augustinus. Trouens, Calvyn kan sonder twyfel as 'die vader van die gereformeerde teologie' beskou word. Saam met Calvyn dien die gereformeerde belydenisskrifte - en dan nie net die Drie Formuliere van Eenheid nie - as 'n soort denkraamwerk waarbinne die gereformeerde teologie beweeg. Ons het reeds daarop gewys dat dit 'n vrye gebondenheid is en nie 'n slaafse gebondenheid nie, aangesien slegs aan die Skrif die hoogste gehoorsaamheid toekom.

Gereformeerde teologie gryp nie net terug na die teologie van die verlede nie, maar hou ook deeglik rekening met die teologie van die hede. Dit hou selfs rekening met die meer kritiese teologiebeoefening, dit luister na Bultmann en Barth, na Moltmann en Pannenberg, na die Charismatiese en bevrydingsteologieë, selfs na die Roomse en Oosters-Ortodokse teologieë. Die gereformeerde teologie soek in hierdie teologieë na waarheidsmomente - wat waardeer kan word - maar dit staan (selfs skerp) afwysend teenoor elke teologiese beskouing wat nie die toets van die Skrif kan deurstaan nie. As sodanig dra die gereformeerde teologie ook 'n polemiese en apologetiese karakter.

\section{Gereformeerde teologie is koninkryksteologie}

Die koninkryk van God moet gesien word as die wesenlike inhoud, die kern en die doel van die ganse wêreldgeskiedenis (Bavinck, s.j.:51). Die boodskap van die koninkryk van God staan sentraal in die Bybelse verkondiging (vgl. Ridderbos, 1950; Bright, 1953; Van der Walt, 1962). As hierdie stellings korrek is, dan vloei logies daaruit voort dat die koninkryk van God ' $n$ sentrale plek in die teologie moet inneem en daarom moet dit betreur word dat die eskatologie in die Institusie (vgl. 3.25) van Calvyn so onderontwikkel is. Die sestiende-eeuse Reformasie het ook meer gehandel oor 'n ware geloof (teenoor werkheiligheid) en 'n ware kerk (teenoor 'n valse kerk) as oor 'n ware koninkryk. Dit is ook opvallend dat haas geen gereformeerde standaarddogmatiekhandboek 'n aparte locus oor die koninkryk bevat nie. Dit is te meer eienaardig as daaraan gedink word dat Augustinus met sy De civitate Dei reeds die eerste ontwerp van 'n teologie van die koninkryk gelewer het. Tereg het Van Ruler (1971:98-100) opge- 
merk dat die gereformeerde teologie die ecclesia binne die basilea plaas en dat die gereformeerde teologie gekastreer is as die teokratiese visioen verbleek (Van Ruler, 1971:97; vgl. veral 1978:29-42). Die teologie handel immers oor méér as die heil van die mens (Jonker, 1974:250); ook die kerk en die kosmos kom binne die gesigsveld van nadenke. Teologie moet beoefen word in verantwoordelikheid teenoor die kerk én die wêreld (Moltmann, 1988:36). Verskillende teoloë vestig daarom tereg die aandag op die eskatologiese aard van die teologie (Ridderbos, 1968:196-197; König, 1978: 193-195, 197-198; Hesselink, 1983:108-112).

Die vraag kan gestel word of die verbond nie net so 'n sentrale tema in die Skrif is as die koninkryk nie (Jonker, 1974:258; Wentsel, 1982:145 e.v.; 1987:207 e.v.; König, 1988:355-364) en of daar nie ook ten regte van verbondsteologie gepraat kan word nie. "Die leer van die verbond is (immers) nêrens so deeglik en omvattend uitgewerk as in die gereformeerde teologie nie" (Jonker, 1994:44). Tog is dit 'n volkome onvrugbare debat om twee temas soos verbond en koninkryk, wat in die Skrif spanningloos langs mekaar funksioneer, in 'n óf-óf-skema te probeer hanteer. Albei handel immers oor die heilsame verhouding tussen God en sy skepping (vgl. Spykman, 1992:11-12). Die verbond beklemtoon die liefdevolle gemeenskap tussen God en mens, die koninkryk weer die genadige heerskappy van God oor die mens en wêreld (Wentsel, 1987:233-235; König, 1983:40 e.v.); die verbond bring gemeenskap, die koninkryk vra gehoorsaamheid. Die verbond dui op die omvattende en genadige verhouding van die gemeenskap waarin God met sy volk wil leef (König, 1986:104-105), terwyl die koninkryk veral dui op God se handeling met die wêreld (Van Ruler, 1978:33). 'n Mens sou die verbond kon tipeer as die inwendige gestalte van die koninkryk en die koninkryk as die uitwendige gestalte van die verbond. Die koninkryk van God is in 'n sekere sin die 'sentrale' tema van die ganse Bybelse verkondiging (Ridderbos, 1950:5, 33, 35, 39; Van Ruler, 1978:32). In eskatologiese perspektief kan gesê word dat die koninkryk ' $n$ meer omvattende tema is.

Goeie teologie is eskatologiese teologie, teologie van die hoop, maar sonder om te vergeet dat dit ook teologie van die geloof en teologie van die liefde is. Gereformeerde teologie help om antwoorde te gee op wat ons glo, wat ons doen (liefde) en wat ons hoop. Gereformeerde teologie handel dus gesien die koninkryksperspektief - nie net oor ortodoksie nie maar ook oor ortopraksie (Moltmann, 1988:104), nie net oor hoe die werklikheid anders verstaan kan word nie maar ook hoe die werklikheid verander kan word 
(Moltmann, 1969:68; 1988:31). Wat nodig is, is nie net (wetenskaplike) kennis nie maar ook (daadwerklike) liefde (1 Kor. 13:2), dus 'n praktiesgeoriënteerde teologie (Rossouw, 1990:67). "If theory without praxis is empty, praxis without theory is blind" (Migliore, 1991:8). Inderdaad is daar in die gereformeerde teologie steeds 'n swaar aksent gelê op die roeping en verantwoordelikheid van die gelowige in die samelewing. As sodanig voldoen die gereformeerde teologie aan die drie kriteria wat Van Huyssteen (1986:173-214) vir die sistematiese teologie daargestel het, naamlik dat dit (1) werklikheidsbetrokke, (2) krities en probleemoplossend en (3) ontwerpend en progressief moet wees. Maar ons het reeds gesien dat daar ook ander - en fundamenteler - kriteria is.

In Suid-Afrika was dit veral die Potchefstroomse teologie wat die koninkryksgedagte tot hoofgedagte van die teologie probeer uitbou het (S. du Toit en J.L. Helberg wat die Ou Testament betref, en W.J. Snyman en L. Floor ten opsigte van die Nuwe Testament). Mede hierdeur beïnvloed, het veral J.A. Heyns 'n omvattende 'teologie van die koninkryk' probeer ontwerp (vgl. Theron, 1984). Inderdaad lewer dit oor die hele veld van die teologie verrassende resultate indien vanuit die koninkryk gedink word vir die ekklesiologie is dit waarskynlik die enigste geneesmiddel teen 'n kerksentriese en kerkistiese benadering. Ook die politieke etiek word vrugbaarder vanuit die eskatologie as vanuit die protologie (voorsienigheidsleer) benader (De Gruchy, 1991:87).

Wanneer dit alles gesê is, moet toegegee word dat die gereformeerde teologie in Suid-Afrika onder skerp kritiek deurgeloop het. Daar is beweer dat die aandag vir 'n geprivatiseerde en geïndividualiseerde verstaan van die Christelike geloof die reformatoriese verbintenis tot sosiale transformasie erg ondermyn het (De Gruchy, 1991:178); verder dat die kerkorde en kerklike legalisme die gereformeerde kerke daarvan weerhou het om teen onreg te getuig (De Gruchy, 1991:205). Inderdaad is dit 'n beskamende en verstommende verhaal hoe die gereformeerde teologie in SuidAfrika in die suigkrag van ' $n$ bepaalde politieke ideologie vasgevang kon word en homself met groot moeite en tydsaam daaraan kon ontworstel het (vgl. Van Wyk, 1993:39-60). Dit toon baie duidelik dat geen enkele teologie - ook die suiwerste - by voorbaat en outomaties teen ideologisering en afbuiging gevrywaar is nie. Teologie is theologia viatorum en daar moet voortdurend teen ontaarding gewaak word en vir bewaring gebid word. Theologia reformata bly steeds theologia reformanda. 


\section{Gereformeerde teologie is kontekstuele teologie}

Ek kom by 'n laaste - en miskien ietwat omstrede - tipering: gereformeerde teologie is kontekstuele teologie. Inderdaad is daar al veel oor kontekstuele teologie besin (vgl. Tennekes \& Vroom, 1989; Hesselgrave \& Rommen, 1989; Bevans, 1992), ook wat Suid-Afrika betref (vgl. VillaVicencio, 1981:3-22; Bosch, 1991a:420-432; Bosch, 1991b:12-17; Mpumlwana, 1993:5-18; West, 1993:1-17; Cochrane, 1993b:116-130).

Dit is foutief om te meen dat gereformeerde teologie nie kontekstuele teologie is nie. Geen teologie is sonder konteks nie - en dus wêreldvreemd eenvoudig omdat die Woord op die werklikheid betrokke is. Die vraag is dus nie of gereformeerde teologie kontekstueel is of nie, maar die vraag is wat die aard van daardie kontekstualiteit is. Saam met Van Genderen (1993:1 10-111; ook Bosch, 1991b:15) onderskei ek graag tussen kontekstuele en kontekstualistiese teologie.

Het Woord van God moet hier en nu in ons leven binnenkomen en gestalte krijgen in al onze relaties en situaties, maar zonder dat er iets van de bijbelse boodschap prijsgegeven wordt. Dit kan men de legitieme contextualiteit noemen. (Van Genderen, 1993:110.)

In kontekstuele teologie word die Woord en werklikheid sodanig op mekaar betrek dat die Woord in die werklikheid ingaan maar nie daarin opgaan nie (soos in die kontekstualistiese teologie). Gereformeerde teologie verleen erkenning aan die konteks waarbinne dit beoefen word, sonder om aan die konteks voorrang bo die Woord te gee. Gereformeerde teologie is anti-dosetisties (Berkhof, 1982:68; vgl. De Gruchy, 1991:70).

Kontekstualistiese teologie word meesal in bepaalde gestaltes van die bevrydingsteologie aangetref (vgl. Martey, 1993) - hoewel daar ook doelbewuste pogings was om gereformeerde teologie en bevrydingsteologie met mekaar te versoen (vgl. De Gruchy, 1991; Migliore, 1991). Maimela (1988:333) is van oordeel dat die bevrydingsteologie vandag die enigste relevante teologie in Suid-Afrika is, want dit begin met teologiese refleksie in die konteks van die onderdrukte en na analise van die situasie (1988: $328,330)$. Wat ons tot dusver in Suid-Afrika gehad het, was 'n abstrakte, onderdrukkende en wit koloniale teologie (Maimela, 1988:323-324; vgl. Maimela, 1990:171-205). In hierdie verband word 'n pleidooi gelewer vir 'n teologie van rekonstruksie (Villa-Vicencio, 1992; vgl. 1981).

Soos 'n kontekslose teologie is 'n kontekstualistiese teologie nie 'n ongemengde seën nie en is daarteen fundamentele kritiek in te bring (vgl. 
Bosch, 1991a:425-432; Bosch, 1991b:12-17). Ons het reeds gewys op 'n reduksionistiese en eklektiese Skrifgebruik. Voorts is daar die gevaar dat die evangelie nie na die konteks gebring word nie maar uit die konteks afgelei word. Soos Nolan (1988:27) sê: "You do not incarnate good news into a situation, good news arises out of a situation". By Calvyn funksioneer die Skrif as ' $n$ lens om die werklikheid te verstaan, terwyl by Martey (1993:137, 141) presies die omgekeerde gebeur. Die konteks, hoewel 'n belangrike faktor, mag egter nooit deurslaggewend wees nie; die prioriteit kom aan die Skrif toe. Verder is daar die ander groot gevaar dat (die wil van) God met die historiese proses geïdentifiseer sal word en dat dié proses gesakraliseer word (soos by Nolan, 1988:166). Daar is in die bevrydingsteologie nog te veel eiegeregtigheid en te weinig eieskuldbesef (Martey, 1993:131, 143), terwyl die bekeringsoproep eintlik totaal verdwyn (Martey, 1993:141; vgl. Jonker, 1994:174). Die identifikasie van verlossing en bevryding, van heil en heiliging, hoewel dit nie geskei mag word nie (tereg by De Gruchy, 1991:179, 180), kan baie maklik tot legalisme aanleiding gee en gevolglik tot 'n onderwaardering van die eskatologie. Tereg onderskei De Gruchy (1991:183-184, 278) - sonder om te skei - tussen die voorlopige en finale (gestaltes van die koninkryk). Sowel die heil as heiliging is genade (Runia, 1984:45).

Volgens Moltmann (1988:58, 101-103) is die kwessie van menseregte en die ekologiese vraagstuk van die belangrikste vrae wat die teologie tans besig hou (vgl. Küng \& Tracey, 1989:445-452). 'n Verantwoorde kontekstuele teologie in Suid-Afrika en Afrika sal myns insiens in besonder aan die volgende ses aspekte moet aandag gee:

(1) 'n Teologiese besinning oor ekonomie (armoede, werkloosheid, regstellende aksie) (Van Wyk, 1993:78-83).

(2) 'n Teologiese besinning oor demografie (bevolkingsontploffing en gesinsbeplanning).

(3) 'n Teologiese besinning oor ekologie (omgewingsbesoedeling en -bewaring); (politieke bevryding sonder omgewingsbewaring is immers 'n leë bevryding, De Gruchy, 1991:115).

(4) 'n Teologiese besinning oor polemologie (geweld, verset, rebellie, rewolusie, oorlog).

(5) 'n Teologiese besinning oor religie (Afrika- en wêreldgodsdienste). 
(6) 'n Teologiese besinning oor ideologie ('n verideologiseerde kerk, selfs met die suiwerste belydenis, neig immers na 'n valse kerk) (De Gruchy, 1991:208).

Veral die verhouding tussen teologie en ideologie moet in Suid-Afrika besondere aandag ontvang. Weinig sake is immers vir 'n samelewing só gevaarlik as 'n verideologiseerde teologie (Janson, 1967; Goudzwaard, 1984; Ericksen, 1986; Leatt et al., 1986; vgl. Esterhuyse et al., 1987).

\section{Slot}

Ek sluit af deur op enkele gevare te wys wat die gereformeerde teologie voortdurend bedreig (vgl. Heyns, 1969:96-160; 1971:15-31):

- Die gevaar van ortodoksisme, waar die belydenis eerder geglo word in plaas daarvan dat die geloof bely word (Bavinck, 1918:44).

- Die gevaar van ideologisme, waar 'n teologie so met 'n ideologie verstrengel raak dat nie meer tussen teologie en ideologie onderskei kan word nie.

- Die gevaar van kwiëtisme, waar die teologie swyg as dit moet profeteer.

- Die gevaar van intellektualisme (rasionalisme), waar die teologie 'n knieval voor die menslike rede en menslike outonomie maak.

- Die gevaar van modernisme (sekularisme), waar die teologie voor die tydsgees swig.

- Die gevaar van tradisionalisme, waar die teologie terugval in Romanisme en die Skrif aan die tradisie opoffer.

Vir hierdie - en ander - gevare sal die gereformeerde teologie voortdurend op sy hoede moet wees.

Die gereformeerde teologie sal hom nougeset met sy onoorsienbare taak moet besig hou, 'n taak wat myns insiens in artikel 18 van die Kerkorde ietwat beperkend geformuleer is. (Artikel 18 bepaal dat dit die diensplig van professore is om bedienaars van die Woord op te lei, die Heilige Skrif uit te lê en die suiwere leer teen die ketterye en dwalinge te verdedig.) Waar Ridderbos (1968:191-197; vgl. Wentsel, 1981:31-32; Bosch, 1992: 8-23; Smit, 1992:88-110; Burden, 1994:135-137) die beoefening van teologie met drie aspekte in verband bring (geloof, kerk en koninkryk), moet myns insiens vier aspekte genoem word: 
* Die heil van die mens.

* Die heiliging van die lewe (kerk).

* Die heling van die samelewing.

* Die heling van die omgewing.

Elke teologie wat geloofsondermynend, kerkverwoestend en koninkryksvernietigend werk, is 'n slégte teologie en waarskynlik géén teologie nie. Omgekeerd, elke teologie wat die geloof versterk, die kerk laat groei en die koninkryk bevorder, is goeie teologie. Só wil die gereformeerde teologie graag wees.

\section{Bronnelys}

BARTH, K. 1955. Die Kirchliche Dogmatik II. Zürich : Zollikon.

BARTH, K. 1988. Evangelical Theology: An Introduction. Grand Rapids : Eerdmans.

BAUMAN, M. 1990. Roundtable: Conversations with European Theologians. Grand Rapids : Baker.

BAVINCK, H. s.j. Kennis en leuen. Kampen : Kok.

BAVINCK, H. 1918. De zekerheid des geloofs. Kampen : Kok.

BAVINCK, H. 1928. Gereformeerde Dogmatiek I. Kampen : Kok.

BAVINCK, H. 1929. Gereformeerde Dogmatiek 3. Kampen : Kok.

BERKHOF, H. 1960. God voorwerp van de wetenschap? Nijkerk: Callenbach.

BERKHOF, H. 1982. Inleiding tot de studie van de dogmatiek. Kampen : Kok.

BERKHOF, H. 1990. Christelijk Geloof: Een inleiding tot de geloofsleer. Nijkerk : Callenbach.

BERKOUWER, G.C. 1969. Verontrusting en verantwoordelikheid. Kampen : Kok.

BERKOUWER, G.C. 1974. Een halve eeuw theologie: Motieven en stromingen van 1920 tot heden. Kampen : Kok.

BEVANS, S.B. 1992. Models of Contextual Theology. Maryknoll : Orbis.

BOSCH, D.J. 1991a. Transforming Missions: Paradigm Shifts in Theology of Mission. Maryknoll : Orbis.

BOSCH, D.J. 1991b. The Nature of Theological Education. Journal of Theology for Southern Africa, 77:3-17, Dec.

BOSCH, D.J. 1992. The Nature of Theological Education. Theologia Evangelica, 25(1): 8-23, March.

BOUWSMA, W.J. 1988. John Calvin: A Sixteenth Century Portrait. Oxford : Oxford University Press.

BREMMER, R.H. 1961. Herman Bavinck als dogmatikus. Kampen : Kok.

BREMMER, R.H. 1991. In gesprek met oudere en nieuwere theologen: De actualiteit van de gereformeerde theologie. Kampen : Kok. 
BRIGHT, J. 1953. The Kingdom of God: The Biblical Concept and Its Meaning for the Church. Nashville : Abingdon Press.

BROWN, H.O.J. 1979. The Conservative Option. (In Gundry, S.N. \& Johnson, A.F. ed. Tensions in Contemporary Theology. Chicago : Moody Press. p. 437-470).

BURDEN, J.J. 1994. Teologiese opleiding in Suid-Afrika: 'n Toekomsblik. Hervormde Teologiese Studies, 50(1 \& 2): 111-139, Maart/Junie.

CALVYN se Kategismus (1981). Potchefstroom : PTP. (Vertaling H.W. Simpson.)

CALVYN, J. 1984/1986/1988/1992. Institusie van die Christelike Godsdiens 1559. Potchefstroom : CJB. (Vertaling H.W. Simpson.)

COCHRANE, J. 1993a. How Should the Clergy be Trained? Challenge, 11:20-21, Dec/Jan.

COCHRANE, J.R. 1993b. The Grave, the Song and a Gestalt: Theology as Pregnant with Context: Contextual Impregnation as the Substance of Theology. Scriptura (Special Issue S I1): 116-130.

DE GRUCHY, J.W. 1991. Liberating Reformed Theology: A South African Contribution to an Ecumenical Debate. Grand Rapids : Eerdmans.

Dei Verbum: Dogmatische Constitutie over de Goddelijke openbaring. 1966. Hilversum : Gooi \& Sticht.

DEIST, F.E. 1994. Moet teologiese opleiding kerklik-konfessioneel wees? Hervormde Teologiese Studies, 50(1\&2): 53-67, Maart/Junie.

DU TOIT, A.B. 1986. Kerk en teologie: twee wederkerig afhanklike groothede. Ned Geref Teologiese Tydskrif, 27(4):391-401, September.

DU TOIT, A.B. 1988. Teologiese weerbaarheid as kerklike vereiste. Ons teologiese opleiding onder die loep. Skrif en Kerk, 9(1):10-21.

DU TOIT, S. 1967. Teologie in 'n tyd van sekularisme. In die Skriflig, 4:1-19, Augustus-September.

ERICKSEN, R.P. 1986. Theologians under Hitler. New Haven : Yale University Press.

ESTERHUYSE, W.P., DU TOIT, P.V.D.P. \& VAN NIEKERK, A.A. 1987. Moderne politieke ideologieë. Johannesburg : Southern Boekuitgewers.

GEORGE, T. 1988. Theology of the Reformers. Nashville : Broadman Press.

GOUDZWAARD, B. 1984. Idols of Our Time. Sioux Center, lowa : Dordt College Press.

GRAAFLAND, C. 1973. Waarom nog gereformeerd? Kampen : Kok.

GREIJDANUS, S. 1946. Schriftbeginselen ter Schriftverklaring. Kampen : Kok.

HESSELGRAVE, D.J. \& ROMMEN, E. 1989. Contextualization: Meanings, Methods and Models. Leicester : Apollos.

HESSELINK, I.J. 1983. On Being Reformed: Distinctive Characteristics and Common Misunderstandings. Ann Arbor : Servant Books. 
HEYNS, J.A. 1969. Sterwende Christendom? 'n Teologie in die greep van die tydgees. Kaapstad : Tafelberg.

HEYNS, J.A. 1971. Die huidige stand van die gereformeerde teologie in $\mathrm{Ne}-$ derland en ons verantwoordelikheid. Pretoria : U P.

JANSON, M. 1967. Die kerk en die ideologie: Toe 'n volk so byna deur 'n teologie vernietig is. Potchefstroom : Die Evangelis.

JONKER, W.D. 1973. Dogmatiek en Heilige Skrif. (In Bakker, J.T et al. (red.). Septuagesimo Anno: Theologische opstellen aangeboden aan prof. dr. G.C. Berkouwer. Kampen : Kok. p. 86-111.)

JONKER, W.D. \& HEYNS, J.A. 1974. Op weg met die teologie. Pretoria : N.G. Kerkboekhandel (hfst 3).

JONKER, W.D. 1989a. Die eie-aard van die gereformeerde spiritualiteit. Ned Geref Teologiese Tydskrif, 30(3): 288-299, Julie.

JONKER, W.D. 1989b. Uit vrye guns alleen: Oor uitverkiesing en verbond. Pretoria : N.G. Kerkboekhandel.

JONKER, W.D. 1993. Die moderne belydenisbeweging in Suid-Afrika - en Calvyn. In die Skriflig, 27(4):443-461, Desember.

JONKER, W.D. 1994. Bevrydende waarheid: Die karakter van die gereformeerde belydenis. Wellington: Hugenote-Uitgewers.

KLOOSTER, F.H. 1979. The Uniqueness of Reformed Theology: A Preliminary Attempt at Description. Calvin Theological Journal, 14(1):32-54, April.

KONIG, A. 1978. Sistematiese teologie. (In Eybers, I.H. König, A. \& Stoop, J.A. Inleiding in die teologie. Pretoria : NG Kerkboekhandel. p. 138-203.)

KONIG, A. 1983. Heil en heilsweg. Pretoria : N.G. Kerkboekhandel.

KÖNIG, A. 1986. Die doop as kinderdoop én grootdoop. Pretoria : N.G. Kerkboekhandel

KÖNIG, A. 1988. Koninkryksteologie of verbondsteologie. Hervormde Teologiese Studies, 44(2):355-364, Junie.

KUHN, U. 1985. Die Kirche als Ort der Theologie. Kerygma und Dogma, 31 (2):98-115, April/Junie.

KUNG, H. \& TRACY, D. ed. 1989. Paradigm Change in Theology: A Symposium for the Future. Edinburgh : T. \& T. Clark.

KUITERT, H.M. 1974. Zonder geloof vaart niemand wel: Een plaatsbepaling van christendom en kerk. Baarn : Ten Have.

KUITERT, H.M. 1992. Het algemeen betwijfeld Christelijk geloof: Een herziening. Baam : Ten Have.

KUYPER, A. 1893. E Voto Dordraceno: Toelichting op den Heidelbergschen Catechismus. Deel II. Amsterdam : Wormser.

KUYPER, A. 1909. Ecyclopedie der Heilige Godgeleerdheid Deel 2. Kampen : Kok.

LEATT, J., KNEIFEL, T. \& NÜRNBERGER, K. ed. 1986. Contending ideologies in South Africa. Grand Rapids: Eerdmans. 
LECERF, A. 1981. An Introduction to Reformed Dogmatics. Grand Rapids : Baker. (Translation A. Schlemmer.)

LEITH, J. 1977. An Introduction to the Reformed Tradition. Richmond Va : John Knox Press.

MAIMELA, S.S. 1988. Doing Theology in South Africa after the Kairos Document. (In Mouton, J. et al. (ed). Paradigms and Progress in Theology. Pretoria : HSRC. p. 321-334.)

MAIMELA, S.S. 1990. Modern Trends in Theology. Braamfontein : Skotaville.

MARTEY, E. 1993. African Theology: Inculturation and Liberation. Maryknoll Ny : Orbis.

McGRATH, A.E. 1991. A Life of John Calvin: A Study in Shaping of Western Culture. Oxford : Basil Blackwell.

McKIM, D.K. 1992. Major Themes in the Reformed Tradition. Grand Rapids : Eerdmans.

MIGLIORE, D.L. 1991. Faith Seeking Understanding: An Introduction to Christian Theology. Grand Rapids : Eerdmans.

MOLTMANN, J. 1969. Theologie van de hoop. Utrecht : Ambo.

MOLTMANN, J. 1988. Wat is theologie? De weg van de theologie in de twintigste eeuw. Baam : Ten Have.

MPUMLWANA, M.M. 1993. The Road to Democracy: The Role of Contextual Theology. Journal of Theology for Southern Africa, 85:5-18, Dec.

NICOL, W. 1989. Gereformeerde meditasie. (In Theron, P.F. \& Kinghom, J. red. Koninkryk, kerk en kosmos: Huldigingsbundel ter ere van prof. W.D. Jonker. Bloemfontein : Pro Christo. p. 48-63.)

NIESEL, W. 1980. The Theology of Calvin. Grand Rapids : Baker.

NOLAN, A. 1988. God in South Africa: The Challenge of the Gospel. Kaapstad : David Philip.

NOORDMANS, O. 1979. Verzamelde Werken II. Kampen : Kok.

NOORDMANS, O. 1981. Verzamelde Werken III. Kampen : Kok.

OOSTHUIZEN, M.J. 1993. Towards an Ethics of Interpretation: The Use of Scripture in Three Recent Christian Documents. Hervormde Teologiese Studies, 49(1 \& 2):167-187, Maart/Junie.

OSTERHAVEN, M.E. 1971. The Spirit of the Reformed Tradition. Grand Rapids : Eerdmans.

POLMAN, A.D.R. 1969. Gereformeerd Katholieke Dogmatiek: Een compendium. Kampen : Kok.

RADDATZ, F.J. 1976. Karl Marx: Een politieke biografie. Baarn : Het Wereldvenster.

RAMEY, R.H. \& JOHNSON, B.C. 1991. Living the Christian Life: A Guide to Reformed Spirituality. Louisville : John Knox.

RICE, H.L. 1991. Reformed Spirituality: An Introduction to Believers. Louisville : John Knox. 
RIDDERBOS, H. 1950. De komst van het koninkrijk: Jezus' prediking volgens de synoptische evangeliën. Kampen : Kok.

RIDDERBOS, H.N. 1968. Het Woord, het rijk en onze verlegenheid. Kampen : Kok.

ROSCAM ABBING, P.J. z.j. Oriëntatie in de theologische wetenschap. Kampen : Kok.

ROSSOUW, H.W. 1990. Teologiese onderwys ná 130 jaar: 'n Toekomsperspektief. Ned Geref Teologiese Tydskrif, 31(1):63-71, Maart.

RUNIA, K. 1984. Evangelisch-Reformatorisch-Gereformeerd. Apeldoom : Willem de Zwijgerstichting.

SMIT, D.J. 1988. Wat is gereformeerde spiritualiteit? Ned Geref Teologiese Tydskrif, 29(2):182-193, April.

SMIT, D.J. 1992. Reformed Theology in South Africa: A Story of Many Stories. Acta Theologica, 12(1):88-110.

SMIT, J.H. 1991. Die toepaslikheid van vier onlangse kerklike dokumente vir reformasie in Suid-Afrika. (In Van der Walt, B.J. red. Die idee van reformasie: Gister en vandag. Potchefstroom : PUCHO/IRS. p. 303-369.)

SPYKMAN, G.J. 1992. Reformational Theology: A New Paradigm for Doing Dogmatics. Grand Rapids : Eerdmans.

STRAUSS, P.J. 1993. Op die tweesprong? Die Ned Geref Kerk oor die tema "kerk in samelewing" in Die Kerkorde en Kerk en samelewing - 1990. Bloemfontein : UOVS.

TENNEKES, J. \& VROOM, H.M. 1989. Contextualiteit en Christelijk geloof. Kampen : Kok.

THERON, D.F. 1984. Die koninkryk van God in die teologie van J.A. Heyns. Pretoria : Unisa. (D. Th.-proefskrif.)

VAN DER WALT, B.J. red. 1991. Die idee van reformasie: Gister en vandag. Potchefstroom : PUCHO/IRS.

VAN DER WALT, T. 1962. Die koninkryk van God - naby! Kampen : Kok.

VAN EGMOND, A. 1992. En spannend leven: Gereformeerd van 1892 tot 1992. (In Brinkman, M.E. red. 100 Jaar teologie: Aspecten van een eeuw theologie in de Gereformeerde Kerken in Nederland (1892-1992). Kampen : Kok. p. 283-318.)

VAN GENDEREN, J. \& VELEMA, W.H. 1992. Beknopte Gereformeerde Dogmatiek. Kampen : Kok.

VAN GENDEREN, J. 1975. Confessie en theologie. Kampen : Kok.

VAN GENDEREN, J. 1993. Naar de norm van het Woord. Kampen : Kok.

VAN HUYSSTEEN, W. 1986. Teologie as kritiese geloofsverantwoording. Pretoria : RGN.

VAN RULER, A.A. 1971. Theologisch Werk II. Nijkerk : Callenbach.

VAN RULER, A.A. 1973. Theologisch Werk VI. Nijkerk : Callenbach.

VAN RULER, A.A. 1978. Verwachtingen voltooiing: Een bundel theologische opstellen en voordrachten. Nijkerk : Callenbach. 
VAN WYK, J.H. 1974. Die vraag na 'n nuwe belydenisskrif. In die Skriflig, 8(32):22-33, Desember.

VAN WYK, J.H. 1980. 'n Oorsig oor die na-oorlogse teologiese ontwikkeling in die Gereformeerde Kerk in Suid-Afrika (GKSA). In die Skriflig, 14(54): 27-50, Junie.

VAN WYK, J.H. 1984. Die Gereformeerde Kerke in Suid-Afrika na 125 jaar. In die Skriflig, 18(70):3-19, Julie.

VAN WYK, J.H. 1986. Die boodskap van die Reformasie vir vandag. Potchefstroom : IRS.

VAN WYK, J.H. 1989. Die Woord is waardevol. Potchefstroom : PU vir CHO.

VAN WYK, J.H. 1991. Moraliteit en verantwoordelikheid: Opstelle oor politieke etiek. Potchefstroom : PU vir CHO.

VAN WYK, J.H. 1993. Temas uit die kerkgeskiedenis. In die Skriflig, 27(2): 281-288, Junie.

VEENHOF, J. 1992. Geschiedenis van theologie en spiritualiteit in de gereformeerde kerken. (In Brinkman, M.E. red. 100 Jaar teologie: Aspecten van een eeuw theologie in de Gereformeerde Kerken in Nederland (18921992). Kampen : Kok. p. 14-95.)

VELEMA, W.H. 1990. Nieuw zicht op gereformeerde spiritualiteit. Kampen : Kok Voorhoeve.

VILLA-VICENCIO, C. 1981. The Use of Scripture in Theology: Towards a Contextual Hermeneutics. Journal of Theology for Southern Africa, 37:322, Desember.

VILLA-VICENCIO, C. 1992. A Theology of Reconstruction: Nation-Building and Human Rights. Kaapstad : David Philip.

WENDEL, F. 1978. Calvin: The Origins and Development of His Religious Thought. London : Collins.

WENTSEL, B. 1981. Het Woord, de Zoon en de dienst: Dogmatiek deel I. Kampen : Kok.

WENTSEL, B. 1982. De openbaring, het verbond en apriori's: Dogmatiek deel 2. Kampen : Kok.

WENTSEL, B. 1987. God en mens verzoend: Godsleer, mensleer en zondeleer: Dogmatiek deel 3a. Kampen : Kok.

WEST, G. 1991. Biblical Hermeneutics of Liberation: Modes of Reading the Bible in the South African Context. Pietermaritzburg : Cluster.

WEST, G.O. 1993. Engagement, Criticality, and Contextualization: Core Concepts in the Teaching/Learning of Biblical Studies in a South African Context. Scriptura (Special Issue, S11):1-17. 
